\title{
Cartographies of Friendship: Mapping Missionary Women's Educational Networks in Aotearoa/New Zealand 1823-1840
}

\author{
Tanya Fitzgerald \\ School of Education \\ UNITEC Institute of Technology \\ Auckland, New Zealand
}

\section{Introduction}

This article offers a textual map of ways in which two Church Missionary Society (CMS) women, Marianne Coldham Williams and Jane Nelson Williams, established networks predominantly with their evangelical 'sisters' in England that simultaneously supported, justified and reinforced their work as missionary educators in Aotearoa/New Zealand in the period 1823-1840. ${ }^{1}$ Particular attention is paid to mapping textual representations of evangelical women's educative activities and the problematic relationship of authorship and authority in the exchange of correspondence between the cultural and evangelical metropole (England) and the reconfigured and evangelised periphery (Aotearoa/ $\mathrm{New}$ Zealand). Primarily this article presents a textual interpretation of Marianne and Jane's missionary activities that simultaneously supported the imperial ameliorative project and subjected Maori women to their colonising gaze within a colonised space. ${ }^{2}$ As Christian wives and mothers, Marianne and Jane formed close relationships with women from similar evangelical and class backgrounds to form bonds of 'sisterhood' that assisted in the formation of educational networks that regulated and legitimated women's participation in missionary activities. In the exchange of correspondence with their 'sisters' in England, the two evangelical women cast themselves in an authoritative role in the schooling of Maori women in the Bay of Islands area in northern Aotearoa/New Zealand. The educative work of Marianne and Jane was based on assumptions regarding the moral imperative to regenerate Indigenous women through the active intervention and

\footnotetext{
${ }^{1}$ Although mapping can be considered a linear activity, the focus of this article is primarily ways in which texts can be mapped to produce authority and authorship. See A. Blunt, 'Mapping Authorship and Authority: Reading Mary Kingsley's Landscape Descriptions', in A. Blunt \& G. Rose (eds.), Writing Women and Space: Colonial and Postcolonial Geographies (New York: The Guilford Press, 1994), 51-72.

2 The mapping of difference in women's narratives is well explored by C. McEwan, 'Encounters with West African Women: Textual Representations of Difference by White Women Abroad', in Blunt \& Rose, op. cit., (1994), 73-100.
} 
agency of missionary women in their lives, families (whanau) and villages (kainga).

\section{CMS women in Aotearoa/New Zealand}

The late eighteenth and early nineteenth century was a period of expansion in CMS activities in Africa, India, Australia and New Zealand. ${ }^{3}$ The stated objective of the CMS, an Anglican body, was to "promote the glory of God by the promulgation of the Gospel of Christ according to the doctrines and disciplines of the Church of England amongst the heathen' ${ }^{4}$ In an attempt to introduce the tenets of civilisation in its New Zealand mission, the CMS utilised schooling as one of the central mechanisms to inculcate Christian values and practices. More specifically, two missionary educators, Marianne Coldham Williams (1793-1879) and Jane Nelson Williams (1801-1896) were charged with the responsibility to open and manage the first formal mission schools in Paihia in the Bay of Islands area in northern New Zealand. ${ }^{5}$ Their educational efforts were directed at establishing schools for local Nga Puhi ${ }^{6}$ women and resident missionary children. Marianne and Jane were directed to 'improve the degraded state of the New Zealanders' through the provision of 'moral and religious instruction' in order to improve 'their miserable situation'. ${ }^{7}$ As with similar missionary endeavours in Africa, India and the Pacific, this objective was founded on the belief that missionary work for women was solely concerned with converting 'heathen' women to become good Christian wives and mothers. ${ }^{8}$ The emphasis on the rescue of 'fallen women' was pinpointed as an explicit responsibility of evangelical women ostensibly because of their superior moral qualities. ${ }^{9}$

To provide a measure of support for their educative activities, Marianne and Jane

\footnotetext{
${ }^{3}$ E. Stock, The History of the Church Missionary Society: Its Environment, its Men and its Work Vol. 1, (London: CMS, 1899), 68; R. Glen (ed.), Mission and Moko: Aspects of the Work of the Church Missionary Society in New Zealand 1814-1882 (Christchurch: Latimer Press, 1992).

${ }^{4}$ Laws and Regulations of the Church Missionary Society Part II, Church Missionary House, (London: CMS, 1833$), 7$.

${ }^{5}$ T. Fitzgerald, 'In A Different Voice: A Case Study of Marianne and Jane Williams, Missionary Educators in Northern New Zealand, 1823-1835.' PhD thesis, The University of Auckland, 1995. Marianne and Henry Williams arrived in Paihia in August 1823 and Jane and William Williams arrived in March 1826.

${ }^{6} \mathrm{Nga}$ Puhi were at this time the main iwi (tribe) in the Bay of Islands area. While the generic term 'Maori' is used to refer to the wider population of Indigenous people (that is, the tangata whenua of Aotearoa - people of the land), in this article Nga Puhi refers specifically to the local people in the Bay of Islands area. The complexity of naming Maori identity is well argued by P. Fitzsimons \& G. Smith, 'Philosophy and Indigenous Cultural Transformation', Educational Philosophy and Theory, 32(1), 2000, 25-41. The focus of this article is the relationship between CMS women and Nga Puhi women - the local Indigenous community of the Bay of Islands area where the CMS located its activities and Paihia specifically where the Williams' mission station was established

${ }^{7}$ S. Marsden, 'New Zealand Journal 1814-1815', in J.R. Elder (ed.), The Letters and Journals of Samuel Marsden 1765-1838 (Dunedin: Coulls Somerville \& Wilkie, 1932), 61.

${ }^{8}$ For a discussion on missionary women's work in Africa see F. Bowie, D. Kirkwood, \& S. Ardener (eds.), Women and Mission: Past and Present: Anthropological and Historical Perceptions (Oxford: Berg, 1993); in India - see J. Haggis, 'Ironies of Emancipation: Changing Configurations of 'Women's Work' in the 'Mission of Sisterhood' to Indian women', Feminist Review, 65 (2000), 108-126; in the Pacific - see M. Jolly, 'Colonising Women: The Maternal Body and Empire', in S. Gunew \& A. Yeatman (eds.), Feminism and the Politics of Difference (Sydney: Allen \& Unwin, 1993), 103-127.

${ }^{9}$ L. Davidoff \& C. Hall, Family Fortunes: Men and Women of the English Middle Class 1780-1850 (Chicago: University of Chicago Press, 1987).
} 
established and fostered networks predominantly with their evangelical sisters in their 'home' parish of Southwell (Nottinghamshire). In the 1823-1840 period Marianne and Jane produced more than 250 letters and journal entries. Recipients of this correspondence included her sisters-in-law, Lydia Williams Marsh and Catherine (Kate) Williams Heathcote and her mother-in-law, Mary Williams all of whom were resident in England. Included in this network were a number of women in the local Bay of Islands area; namely Charlotte Butcher Kemp and Charlotte Arnett Brown, Marianne's two closest friends. ${ }^{10}$ When Jane and William Williams moved inland to Waimate in 1835 , and then to Turanga (Poverty Bay) in 1840, Marianne corresponded regularly with her sister-in-law. ${ }^{11}$ Two of Marianne's daughters, Marianne Williams Davies (born 1820) and Caroline Williams Hadfield (born 1832) as well as Elizabeth Fairburn Colenso (daughter of Sarah Tuckwell Fairburn who worked with Marianne in the Paihia mission school) corresponded with Marianne's women friends in the New Zealand mission and the Southwell community. ${ }^{12}$ In other words, relationships were established with women from similar evangelical, familial and class backgrounds and this assisted in the maintenance of a network of self-supporting correspondents and contributed to what Antoinette Burton calls the voice of imperial female authority. ${ }^{13}$

The exchange of correspondence promoted a reciprocal relationship between metropole and periphery that simultaneously reinforced missionary women's activities and authoritative positions in both locations. ${ }^{14}$ Such a process was central not only to the affirmation of women and their ongoing participation in missionary work as Joyce Goodman has similarly argued, but a crucial component in the educational and

\footnotetext{
${ }^{10}$ Charlotte Butcher Kemp arrived in Kerikeri, in the Bay of Islands area in 1818, Sarah Tuckwell Fairburn arrived in Paihia in 1821. Sarah's daughter was Elizabeth Fairburn Colenso who was a pupil and teacher at the Paihia mission school and who resided in the Paihia mission station and assisted Marianne with the school. Charlotte Arnett Brown arrived in New Zealand in 1829 and also worked as a missionary teacher. When Charlotte died in 1855 and both Marianne and Jane Williams frequently had her daughter to stay with them as they did not 'approve' of her replacement, Christina Crombie Johnston. See S. Williams, 'Marianne Williams' in The Dictionary of New Zealand Biography, Vol. 1. 1769-1869 (DNZB) (Wellington: Allen \& Unwin/Department of Internal Affairs, 1990), 595-596; F. Williams, 'Jane Williams' in DNZB, Vol. 1, 594; N. Pickmere, 'Charlotte Kemp', in DNZB Vol. 1, 222-223 for further details.

${ }^{11}$ Copies of these letters can be located in F. Porter (ed.), The Turanga Journals: letters and Journals of William and Jane Williams (Wellington: Price Milburn, 1974).

${ }^{12}$ See Fitzgerald, op. cit., (1995) for a fuller discussion of the inclusion of their daughters in their evangelical networks. Ways in which daughters were co-opted as correspondents is also discussed by C. Hobbs (ed.), Nineteenth Century Women Learn to Write (Charlottesville: The University of Virginia Press, 1995).

13 A. Burton, Burdens of History: British Feminists, Indian Women and Imperial Culture 1865-1915 (Chapel Hill: University of North Carolina Press, 1994).

${ }^{14}$ J. Goodman, 'Languages of Female Colonial Authority: The Educational Network of the Ladies Committee of the British and Foreign School Society, 1813-1837', Compare, 30/1 (2000), 7-19; See also A. Stoler \& F. Cooper (eds.), Tensions of Empire: Colonial Cultures in a Bourgeois World (Los Angeles: University of California Press, 1997) for a discussion on the identification of social and political relationships between metropole and colony and M. L. Pratt, Imperial Eyes: Travel Writing and Transculturation (London: Routledge, 1992); S. Morgan, Place Matters: Gendered Geography in Victorian Women's Travel Books about Southeast Asia (New Brunswick: Rutgers Press, 1996) for a detailed discussion on women's travel writing and notions of colonialism
} 
recuperative imperative to 'save' heathen women. ${ }^{15}$ The evangelical rhetoric of rescue therefore simultaneously underpinned and legitimated the intervention of missionary women in the lives of those they deemed most in need of reclamation, Nga Puhi women. ${ }^{16}$

Drawing on evidence from letters and diaries this article maps the construction of educational networks based on evangelical and familial connections that offered Marianne and Jane Williams 'a place to stand from which they could bypass or challenge male-dominated sacred worlds' ${ }^{17}$ The metaphor of mapping that is referred to in this article functions at a number of levels. In the first instance, this metaphor is used to provide a visual representation of Marianne Williams in the domestic setting of the missionary home to map the problematic relationship of authorship, authority and the textual connection with readership. Secondly, letters and diaries exchanged between the cultural and evangelical metropole (England) and the reconfigured and evangelised periphery ${ }^{18}$ (Aotearoa/New Zealand) are mapped as a cartographic record of what Sharp calls 'fictive geography'. ${ }^{19}$ That is, this correspondence charts friendships between and among women, and prescriptive images of women's missionary work to offer an understanding of the complex relationship between centre and periphery in the exchange of religious endeavours between colony and metropole. Thirdly, letters and diaries composed by Marianne and Jane Williams are mapped to provide an understanding of ways in which their letters and diaries served to offer an authoritative gaze that dictated colonial spatial relations. As authors, Marianne and Jane can be understood simultaneously as viewers and reproducers of/within these texts that echoed 'commonly shared knowledge'. ${ }^{20}$ The visual and textual representation of Nga Puhi women who were depicted as 'degraded' and in 'need' of the recuperative possibilities of missionary education legitimated the separation of colonisers (CMS missionaries) from the colonised (Nga Puhi) and the production of a colonised space that sanctioned the active intervention of missionary women in the lives of Nga Puhi women. ${ }^{21}$ Within this colonised space, the authoritative gaze of CMS women reproduced an Anglo-centric ${ }^{22}$ discourse that mapped

\footnotetext{
15 Goodman, op. cit., (2000).

${ }^{16}$ T. Fitzgerald, 'Jumping the Fences: Maori Women's Resistance to Missionary Schooling in Northern New Zealand 1823-1835', Pedagogica Historica, 37/1 (2000), 175-192.

${ }^{17}$ E. Isichei, 'Does Christianity Empower Women?: The Case of the Anaguta of Central Nigeria' in Bowie et al., (1993), 209.

${ }^{18}$ D. Gaitskell, 'Whose Heartland and Which Periphery?: Christian Women Crossing South Africa's Racial Divide in the Twentieth Century', Women's History Review, 11/3 (2002), 375-394.

${ }^{19}$ V. P. Sharp, 'Towards a Critical Analysis of Fictive Geography', Area, 32 (2002), 327-334.

20 A. Stoler, Race and the Education of Desire: Foucault's History of Sexuality and the Colonial Order of Things (North Carolina: Duke University Press), 109.

${ }^{21}$ S. Mills, 'Gender and Colonial Space', Gender, Place \& Culture: A Journal of Feminist Geography, 3/2 (1996), $125-147$.

${ }^{22}$ Here I am referring to an Anglican centred doctrine.
} 
relations between 'Christian' and 'heathen' that simultaneously restricted and confined Nga Puhi women and offered Marianne and Jane Williams a sense of place within their 'mission of domesticity'.23 In other words, these two missionary women played an active role in the colonisation and domestication of Nga Puhi women and their labour. To ignore this would perpetuate, as Blunt and Rose argue, imperial notions of transparent space and its unproblematic representation of the 'Other' as well as itself. ${ }^{24}$ Therefore, as authors of their letters and diaries, Marianne and Jane Williams do not simply function as colonial viewers but produce colonising forms of knowledge that re-present them as 'omniscient observers'. ${ }^{25}$

Representations of missionary women, missionary work and the imposed spatial confinement of 'other' women are deeply problematic. In presenting a reading of these texts it is not my intention to replicate the dominant view but to chart the multiplicity of representations that inform the production of these written texts to map the increasingly problematic silences, gaps and inconsistencies. Written texts cannot simply be viewed as a mirror of missionary women's lives, experiences and activities; they are historically and culturally produced and are a visible form of the norms and values that operated within a Eurocentric space. Although the production of correspondence for exchange was regulated in different ways for missionary men and women, the public nature of women's self-writing destabilises notions of the public/private divide and points to the suggestion that what was produced as private correspondence between evangelical women was subject to public distribution among these women. ${ }^{26}$ As authors these women utilised their network of correspondents to claim an authoritative voice that offered Marianne and Jane Williams a public voice that interpreted and reinforced colonial spatial relations.

\section{Letter and diary writing}

An iconographic image of Marianne Williams was produced when she was over 80 years of age. The setting that is depicted is reminiscent of many middle class drawing rooms in late nineteenth century New Zealand. Floor and wall coverings can be seen within the frame of the photograph and a full vase of flowers sits on the writing table. While such

\footnotetext{
${ }^{23}$ Haggis, op.cit. (2000), 108.

${ }^{24}$ Blunt \& Rose, op. cit., (1994).

${ }^{25}$ G. Rose, Feminism and Geography: The Limits of Geographical Knowledge (Cambridge: Polity Press, 1993), 112.

${ }^{26}$ S. Mills, Discourses of Difference: Women's Travel Writing and Colonialism (London: Routledge, 1991). A reading of the correspondence of Henry Williams (husband of Marianne Williams) and William Williams (husband of Jane Williams) detail a number of 'official' events such as baptisms of local Maori, local committee meetings and Sunday sermons that neither Marianne nor Jane respectively record. One explanation is that it was a responsibility of missionary men to record these 'official' events to account to the CMS of their own work and activities.
} 
portraits might offer a glimpse of life for middle class women in a colonial setting, there are a number of alternate interpretations. In the scene that has been reproduced, Marianne is located as a private individual and the dominant image presented is that of a passive woman in a drawing room sitting writing a letter. ${ }^{27} \mathrm{~A}$ second reading of this photograph re-presents Marianne as an author of her own texts who produced authoritative and self-referential accounts of her activities and experiences. A third interpretation points to the possibility that the produced text was subject to the privileged gaze and re-interpretation of the author that positioned Nga Puhi women as 'other' thereby neutralising threats of difference. ${ }^{28}$ And, finally, these letters and diaries can be viewed as cartographic records of encounters between colonised and coloniser that were written in a colonising language.

In this photograph, Marianne has been caught not looking directly at the camera. As we gaze into the photograph, her gaze is outside the frame and to the periphery of the viewer's vision. There are, as Kate Rousmaniere suggests, deep silences surrounding photographs such as this and several silences that have yet to be interpreted. ${ }^{29}$ For example, although Marianne is portrayed as the only person in this photograph, this does not necessarily suggest that her children and husband are absent from a wider viewing of this scene. We also do not know what has been written in the letter lying on the table or its intended recipient. Nor is it known whether Marianne herself has written this particular letter. For example, on a number of occasions Marianne acted as a scribe for her husband (Henry Williams, 1792-1867) who dictated to her his official letters to the CMS. ${ }^{30}$ On one level this photograph raises questions concerning the visual way Marianne is presented and her apparent passivity. Given her active role as a missionary educator, it is difficult to locate Marianne as a passive individual solely in a domestic setting. Yet this historical artefact is a powerful stereotype that operated to sanction women's participation in work and non-domestic activities. ${ }^{31}$ Although this photograph may represent the iconographic

\footnotetext{
${ }^{27}$ For an account of middle class women and notions of respectability and domesticity see M. Theobald, 'The Woman at the Piano: Women, Education and Culture in the Nineteenth-century Frame of Reference', in M. Theobald, Knowing Women: Origins of Women's Education in Nineteenth Century Australia (Cambridge: Cambridge University Press, 1996), 9-24.

${ }^{28}$ C. Nash, 'Remapping and Renaming: New Cartographies of Identity, Gender and Landscape in Ireland', Feminist Review, 44 (1993), 39-57.

${ }^{29} \mathrm{~K}$. Rousmaniere, 'Questioning the Visual in the History of Education', History of Education, 30/2 (2001), 109-116.

${ }^{30}$ Marianne Williams, 19 March 1828, Letters \& Journals written by the Rev Henry \& Mrs Marianne Williams \& Rev William Williams \& Mrs Jane Williams, 1822-1864, Vol. 2, p. 86, typescript, qMS2225, Alexander Turnbull Library (ATL). Various journal entries for the period July - December 1829 purport to be Henry Williams' account of events but the original letters are written in Marianne Williams' handwriting - see for example Letters \& Journals written by the Rev Henry \& Mrs Marianne Williams \& Rev William Williams \& Mrs Jane Williams, 1822-1864, Vol. 3, p. 9, typescript, qMS2226, ATL. Marianne also penned a question/answer booklet in Maori for use in the Paihia school that was later printed by Colenso in 1840. See He Kupu Ui Mo Te Hunga o Te Kura, n.d., MS1129, ATL. The author of this text was Marianne's brother-in-law, William Williams.

${ }^{31}$ The term non-domestic is used here to signal all activities that were not located in the home setting. As previously argued, the
} 
middle class woman, its accuracy is to be questioned. As a CMS woman, the colonial setting of the Paihia mission station and its environs offered Marianne opportunities to directly participate in missionary work that blurred boundaries between the domestic and the public. ${ }^{32}$

On another level, this photograph raises questions about the text of the letter and its author. What descriptions and experiences have been recorded? What interpretations have been offered? Whose world-view has dominated the sentences and paragraphs? Who might be the anonymous subject(s) of the letter? These questions link with notions of authorship expounded by Foucault who suggested that the figure of an author existed before and beyond the text itself. ${ }^{33}$ As an author, Marianne was conspicuously absent from her letters and diaries, evidenced by the lack of ' $\mathrm{I}$ ' in the text. ${ }^{34}$ This privileged distance from the text, as Foucault has pointed out, offered anonymity and reproduced the 'author-function' that reflected a sense of authenticity and authority. What remains problematic is that Marianne is both narrator of and actor in her own letters and diaries as well as those scripts authored by her sister-in-law. In this way, the authoritative authorial gaze is both subjective and complex and arguably, authorship and authority are inter-related and inseparable.

Cheryl Walker's analysis of 'persona criticism' is useful here in understanding multiple connections between an author, her work and her audience. ${ }^{35}$ A persona is a type of mask worn by an author that represents several subject positions. Authorship by its very nature is complex and contradictory and at different points in the text, different personae may, or may not, be revealed. It is possible for example, that Marianne Williams adopted five shifting identities or masks as an author and/or authoritative persona. As an evangelical woman, she identified in the first instance with her 'sisters' in England with whom she had established relationships based ostensibly on familial connections. Secondly, as a missionary educator she identified primarily with her sister-in-law, Jane Williams who worked and lived with her in the Paihia mission station. Thirdly, as a woman in a frontier society Marianne identified with other missionary wives in northern

public/private divide is inherently problematic particularly in discussions about women's missionary work and activities.

${ }^{32}$ T. Fitzgerald, 'Fences, Boundaries and Imagined Communities: Re-thinking the Construction of Early Mission Schools and Communities in New Zealand 1823-1830', History of Education Review, 30/2 (2001), 14-25.

${ }^{33}$ M. Foucault, 'What is An Author?' in J. Harari (ed.), Textual Strategies: Perspectives in Post-structuralist Criticism (Ithaca: Cornell University Press, 1979), 141-160.

${ }^{34}$ Fitzgerald, op. cit., (1995).

${ }^{35}$ C. Walker, 'Persona Criticism and the Death of an Author', in W. Epstein (ed.), Contesting the Subject: Essays in the Postmodern Theory and Practice of Biography and Biographical Criticism (Bloomington: Indiana University Press, 1991$), 118$. 
New Zealand who provided support, friendship and less frequently, companionship. ${ }^{36}$ Fourthly, Marianne identified as wife of Henry Williams, leader of the CMS mission to New Zealand, and mother of eleven children. ${ }^{37}$ And, finally, as a missionary educator, Marianne self-identified as a saviour of Nga Puhi women, their children and ultimately their families. ${ }^{38}$ These multiple and at times contradictory positions suggest that inter-related notions of authority, authorship and authenticity are deeply ambivalent. ${ }^{39}$ There is however a form of authorial persistence surrounding the form and content of these letters and diaries and the relationship between/among women that is worthy of attention.

As forms of self-writing, the exchange of letters and diaries was a mechanism evangelical women in the Paihia mission station and the parish of Southwell used to establish, nurture and reciprocate networks of friendship based on a commonality of interest centred on the participation of (middle class) women in evangelical work. Maria Tamboukou's analysis of the use of women's autobiographical writing to negotiate a space and place of their own is instructive here. ${ }^{40}$ Letter writing provided a space for CMS women outside of the authority of the Anglican Church and the mission community to 'speak the unthought, unsaid and undervalued'. ${ }^{41}$ This attempt at self-assertion provided a form of private space for Marianne and Jane to exercise a degree of control over what was written, repeated and exchanged. Letter writing as an activity was conducted in the confines of the mission family home. As a specific and permanent place, this structure (both physical and spiritual) offered a sense of belonging and ownership, a site of authenticity and a shelter in a foreign and at times threatening landscape. ${ }^{42}$ The act of writing letters and the production of letters cannot therefore be conceptualised as a neutral act. What is significant is not just what was recorded but what was not recorded. The mapping metaphor might suggest therefore a symbolic 'cartography of silence' that surrounds the anonymity of both reader and writer. ${ }^{43}$

\footnotetext{
${ }^{36}$ For example Charlotte Butcher Kemp and Charlotte Arnett Brown. Marianne also visited and corresponded with two Wesleyan women situated in the Hokianga area in northern New Zealand - Eliza Leigh White and Jane Broggref Hobbs - see Jane Williams to Catherine Heathcote, 29 March 1826, Williams Papers, n.d., Box 11, Folder 99, Item 709, MS 91/75 A(i)a, Auckland Museum Institute Library (AMI).

37 S. Williams, 'Marianne Williams 1793-1879', DNZB Vol. 1, 595.

38 Fitzgerald, op. cit., (2000).

${ }^{39}$ For a detailed analysis of representation and authenticity in autobiography see J. Bush, 'Ladylike Lives: Upper Class Women's Autobiographies and the Politics of Late Victorian and Edwardian Britain', Literature \& History, 10/2 (2001), $42-61$.

${ }^{40}$ M. Tamboukou, 'Spacing Herself: Women in Education', Gender and Education, 11/2 (1999), 125-139.

${ }^{41}$ F. Nussbaum, 'Eighteenth Century Women's Autobiographical Commonplaces', in S. Benstock (ed.), The Private Self: Theory and Practice of Women's Autobiographical Writings, (Chapel Hill: University of North Carolina Press, 1988$), 154$.

${ }^{42}$ This argument is expounded further in Fitzgerald, op. cit., (2001).

${ }^{43}$ S. Stanford Friedman, Mappings: Feminism and the Cultural Geographies of Encounter (New Jersey: Princeton University Press,
} 
Although the CMS may not have required missionary women to submit their letters and diaries for scrutiny, nevertheless the possibility existed that this could occur. This may have therefore tempered descriptions of events and the re-presentations of women's evangelical work and activities. ${ }^{44}$ Yet at the same time accounts of their educative activities may have served to justify women's participation in evangelical work in a mission station geographically remote from England. ${ }^{45}$ In other words, letters and diaries that re-presented positive images of women's missionary activities may have served a dual purpose; the continued presence of women in 'safe' mission stations and to encourage those at 'home' to support missionary endeavours either through donation or their active recruitment to the mission fields. Although nineteenth century social codes shaped the contents of letters the re-telling and re-viewing of their activities and colonial discourses for their readers affirmed notions of difference and distance. Mary Louise Pratt has pointed out that "while the imperial metropolis tends to understand itself as determining the periphery ... it habitually blinds itself to the ways in which the periphery determines the metropolis' ${ }^{46}$ Texts such as letters and diaries written by Marianne and Jane do not offer a smooth history but rather a series of fragments that can never be fully recovered as Peter Hulme has stressed. ${ }^{47}$

Mary Louise Pratt has outlined ways in which women's travel writing in the nineteenth century fostered a process of 'Euroimperialism' whereby these written accounts produced a particular version of the Western world and colonial 'Other' ${ }^{48}$ More specifically, letters and diaries shared within the evangelical network offered accounts that interpreted and re-presented Nga Puhi women as 'other' by stressing differences between Christian and 'heathen' women. ${ }^{49}$ The imperative to describe and explain Nga Puhi women shaped and supported evangelical claims that 'heathen' women needed to be saved by Christian women; an important component of missionary and later colonial policy. ${ }^{50}$ In this way CMS missionaries could act as civilisers of local Maori, rather than be portrayed as conquerors. More significantly, women's role in evangelical work and

\footnotetext{
1998), 3 .

${ }^{44}$ Details such as illnesses, pregnancies and miscarriages were reported in the missionary women's letters and diaries. One of the family descendants, Algar Williams, in preparing transcripts of this material, removed all these details. A detailed search and examination of the original letters has revealed the extent of this form of censorship.

${ }^{45}$ The pre-occupation with creating a landscape that reminded CMS missionaries of England as well as providing a 'safe' location is detailed in Fitzgerald, op. cit., (2001).

${ }^{46}$ Pratt, op. cit., (1992), 6.

${ }^{47}$ P. Hulme, Colonial Encounters: Europe and the Native Caribbean 1492-1797 (London: Methuen, 1986), 12.

${ }^{48}$ Pratt, op. cit., (1992), 4.

${ }^{49}$ Fitzgerald, op. cit., (1995).

${ }^{50} \mathrm{~K}$. Morris Matthews \& K. Jenkins, 'Whose Country is it Anyway? The Construction of a New Identity Through the Schooling for
} 
their own mission to 'save' Nga Puhi women legitimated their public presence in the mission station. As Alison Twells points out in her work on Christian motherhood and missionary work, the positioning of women as redemptive guardians of 'other' women formed a core part of women's evangelical identity. ${ }^{51}$ The use of ameliorative discourses aimed at improving the situation of Indigenous women and justifying women's entry into the public arena was not unique to the New Zealand situation as Ruth Roach Pierson and Nupur Chaudhuri in the case of India ${ }^{52}$ and Margaret Booth in her analysis on colonial education in Swaziland have shown. ${ }^{53}$ The reliance on the labour of wives of missionary men to assist with colonising endeavours was not however a straightforward transfer of domestic labour from the Christian family home to the mission schoolroom. ${ }^{54}$ What was crucial to this process was the agency of women in the co-option of their networks of sisterhood to recuperate Nga Puhi women's lives and in doing so contribute to the imperial project. 55

The language and networks of sisterhood were riddled with flaws. These networks articulated and reinforced differences between women based on class and ethnicity and were instrumental in perpetuating a hierarchy within the Paihia mission station. Eileen Janes Yeo suggests that 'women from middle class backgrounds could unwittingly use languages of motherhood and sisterhood as instruments of power, and end up constraining the possibilities for other women'. ${ }^{56}$ While Marianne and Jane Williams and their 'sisters' may have carved out a public role for themselves via their work as missionary educators, they relied on the domesticated labour of Nga Puhi women to provide these opportunities. ${ }^{57}$ This is a significant consideration in theorising how evangelical women represented and asserted their difference from and superiority over Nga Puhi women and the creation of (white) women's networks based on imperial notions of difference.

\footnotetext{
Maori in Aotearoa/New Zealand', History of Education, 28/3 (1999), 339-350.

${ }^{51}$ A. Twells, 'Let Us Begin at Home: Class, Ethnicity and Christian motherhood in the Writing of Hannah Kilham, 1774-1832', in E. Janes Yeo (ed.), Radical Femininity: Women's Self-representation in the Public Sphere (Manchester: Manchester University Press, 1998), 25-51.

${ }^{52}$ R. Roach Pierson \& N. Chaudhuri (eds.), Nation, Empire and Colony (Bloomington: Indiana University Press, 1998).

${ }^{53}$ M. Booth, 'Education for Liberation or Domestication? Female Education in Colonial Swaziland', in T. Hunt \& M. Lessard (eds.), Women and the Colonial Gaze (New York: New York University Press, 2002), 174-187.

${ }^{54}$ A. Twells, 'Happy English Children - Class, Ethnicity, and the Making of Missionary Women in the Early Nineteenth Century', Women's Studies International Forum, 21/3 (1998), 235-245; J. Haggis, 'White Women and Colonialism: Towards a Non-recuperative History', in C. Midgley (ed.), Gender and Imperialism (Manchester: Manchester University Press, 1998), 45-75.

55 A. Burton, 'Some Trajectories of 'Feminism and Imperialism”, Gender \& History, 10/3 (1998), 558-568.

56 Yeo, op. cit., (1998), 16.

${ }^{57}$ Fitzgerald, op. cit., (2000).
} 


\section{Mapping missionary women's networks}

The formation of networks of sisterhood by Marianne and Jane Williams cannot be considered accidental. As Eileen Janes Yeo has explained, sisterhood based on religious identity was employed to authorise women's entry into activities beyond the family home. ${ }^{58}$ While nineteenth century discourse linked notions of domesticity and femininity, evangelical women's sphere of influence offered opportunities for women to exploit contradictions within evangelical theology that simultaneously represented women as spiritually equal and socially subordinate as Leonore Davidoff and Catherine Hall have persuasively argued. ${ }^{59}$ The central component in the extension of middle class and evangelical women's sphere of influence and (moral) authority was the assertion of difference. That is in the language used to describe their evangelical activities and the construction of networks to support and sustain their work, CMS women such as Marianne and Jane articulated their 'sameness' with other evangelical sisters and their differences from those with whom they did not identify and from whom they distanced themselves; Nga Puhi women and those 'other' missionary women who could not claim identity based on sisterhood. The production and exchange of letters and diaries between/among women created a network that was both self-supporting and exclusionary and offered women a less difficult and more direct involvement in missionary work.

One of the expectations that the CMS placed on its male missionaries was to document their work and regularly communicate with the Parent Body and to keep a journal of proceedings . . . and shall from time to time forward to the Committee . . extracts from it containing matters of interest of importance' ${ }^{60}$ However, there appeared to be no formal expectation that women publicly exchange correspondence with the CMS. Nevertheless the possibility existed that this might occur. In a letter to her Southwell correspondent Catherine Williams Heathcote in December 1835, Jane Williams cautioned her to 'not let this letter go out of your hands' as she was perhaps mindful of the potentially disruptive nature of these letters. ${ }^{61}$ In other words, correspondents may have simultaneously acted as confidantes in the production of colonial forms of knowledge and the legitimising of relationships of difference. The spatial imagery and language of the letters and diaries highlights ways in which these texts operated as spaces that carved out multiple and complex roles for evangelical

\footnotetext{
${ }^{58}$ E. Janes Yeo, 'Protestant Feminists and Catholic Saints in Victorian Britian', in E. Janes Yeo, op. cit., (1998), 127-148.

${ }^{59}$ Davidoff \& Hall, op. cit., (1987), 114-118.

${ }^{60}$ Laws \& Regulations of the Church Missionary Society Part II, Church Missionary House, (London: CMS, 1833), 30.
} 
women.

Terms used by correspondents to address one another provide clues as to the close spatial relationship between/among women. For example, a letter written by Lydia Williams Marsh to Jane Williams in February 1832 referred to 'our fellow women' 62 and she frequently addressed both Catherine Williams Heathcote and Lydia Williams Marsh as 'my dear sister,' 'my dearest Kate' or 'my dear Lydia'. Frequently, the closing line was 'your affectionate sister'. ${ }^{63}$ For Marianne and Jane Williams the affectionate use of the term 'sister' signalled a privileged relationship based on fictive kin rather than on familial kin and was one of the vital components in sustaining this network and friendship. ${ }^{64}$ Prior to her departure from England in 1822, Marianne Williams established her own networks of (women) friends and family members with whom she could correspond. ${ }^{65}$ This included her sisters-in-law, Lydia Williams Marsh and Catherine Williams Heathcote as well as her mother-in-law, Mary Williams. Although a number of letters were specifically addressed to these women, copies of these letters were widely read and dispersed. ${ }^{66}$

This circle of friends was sustained throughout her own life in New Zealand and was maintained by her daughters Marianne Williams Davies and Catherine Williams Hadfield who continued to write to their mother's friends after her death. Furthermore, both Marianne and Jane Williams named their daughters after their friends and sisters-in-law. Marianne's daughter Catherine (born 24 February 1831) was named after her sister-in-law, Catherine Williams Heathcote (who had married Edward Heathcote an organist in the Southwell Church) and Lydia Jane (born 2 December 1834) after her two sisters-in-law Lydia Williams Marsh (sister of Henry who had married Edward Marsh a CMS member and clergyman) and Jane Williams. ${ }^{67}$ When Maria Coldham Morgan ${ }^{68}$,

\footnotetext{
61 Jane Williams to Catherine Heathcote, 2 December 1853, Williams Papers, Box 3, Folder 98, Item 708, AMI.

62 Lydia Marsh to Jane Williams, Williams Papers, Box 1, Folder 44, Item 276, AMI.

63Jane Williams to Lydia Marsh, 21 June 1831, Williams Papers, Box 3, Folder 98, Item 703, AMI. While these women were all related as has been previously pointed out, the term 'sister' was used for female family members as well as friends. The use of terms such as these is discussed by Hobbs, op. cit. (1995). This term was also used to domesticate the readership and this is discussed in a later section of this article.

${ }^{64}$ E. Fox-Genovese, Feminism without Illusions: A Critique of Individualism (Chapel Hill: University of North Carolina Press, 1991), 13.

65 Marianne Williams, Journal, January-July 1822, MS 91/75, A(ii)5, AMI. This journal was written by Marianne prior to her departure for the New Zealand mission and details the anguish Lydia Williams Marsh felt regarding her preparations for the voyage and journey to New Zealand.

${ }^{66}$ This was a common practice for women and men's correspondence. Missionary men were required to submit their journals and (financial and evangelical) accounts of their activities to the Parent Society every three months. Accordingly their accounts were for public disbursement and it was not unusual for excerpts from mission fields to be published in evangelical magazines such as The Missionary Magazine (Edinburgh: J.A. Pillans \& Sons), a periodical monthly magazine that was distributed within church communities. Although women's correspondence was not sent directly to the CMS, it is arguable that the exchange of correspondence and dissemination within the Southwell community can be seen as a form of public examination, particularly as excerpts were used to gain funds ands supplies for missionary work as this article argues.

${ }^{67}$ Names and birth dates are recorded by S. Woods, Marianne Williams; A Study of Life in the Bay of Islands New Zealand 1823-1879 (Christchurch: PPP Printers, 1977), 78. Other details can be found in Porter, op. cit. (1974), 22.
} 
Marianne's 'affectionate' ${ }^{69}$ sister and a single woman missionary ${ }^{70}$ arrived to assist Marianne with the mission school in 1831, she was also included in this self-supporting network. This connection was not solely based on family relationships, as daughters of friends were included in this network. For example, Elizabeth Fairburn Colenso ${ }^{71}$ (whose mother worked with Marianne and Jane in the Paihia mission station) and Mary Davis Matthews whose family had resided at Paihia in the mid-1820s corresponded with Marianne once they left the Paihia area. ${ }^{72}$

The language of these letters suggests that a sense of the personal operated as a means of reducing distance between writer and reader as well as maintaining links with 'home'. For example shortly after her arrival in New Zealand, Marianne commented that she:

... felt a wish to convey every look and every conversation to our absent friends and several times in the course of the day had I said to Mr. Marsden - "I wish our English friends could peep in upon us". ${ }^{73}$

Friendship and kinship appear therefore to be mutually inclusive and as Valerie Sanders has suggested, the use of the term sister was a way of domesticating the readership and reducing it to a family circle. ${ }^{74}$ The representation of scenes such as this for their correspondents reworked family discourse and involved the wider family and faith community in the creation of 'home' in a geographically distant location. ${ }^{75}$ While social distance between missionaries and local Maori may have been emphasised in descriptions of life in the Paihia mission station, rhetoric surrounding the geographical distance between England and New Zealand was constructed as if this separation did not exist. Although distance and separation provoked a sense of being 'overwhelmed at the idea of the immediate distance that separates us from those most dear to us', the articulation of their 'path of duty' provided a necessary justification for missionary work that involved

\footnotetext{
${ }^{68}{ }_{\mathrm{K}}$. Howe, 'John Morgan 1806/7?-1865', DNZB Vol. 1, 299-300.

69 Jane Williams to Catherine Heathcote, 29 May 1835, Williams Papers, Box 11, Folder 98, Item 706, AMI

${ }^{70}$ William Williams, 19 September 1831, Journal 1825-1831, p. 254, qMS 2248, ATL. See also Register of Missionaries (Clerical, Lay and Female) and Native Clergy from 1804-1894. List II, Female Missionaries, (Gilbert \& Revington, London, 1896), 297 and List of Missionaries with Church Missionary Society, 1814-1829, MS849, AMI.

71 J. Murray, 'Elizabeth Colenso 1827-1904', DNZB Vol. 1, 86-87.

${ }^{72}$ List of Missionaries with Church Missionary Society, 1814-1829, MS849, AMI.

${ }^{73}$ Marianne Williams, 7 August 1823, Letters \& Journals, Vol. 1, p. 43, ATL.

${ }^{74}$ V. Sanders, The Private Lives of Victorian Women: Autobiography in Nineteenth Century England (New York: St. Martin's Press, 1989), 14.

${ }^{75}$ See Fitzgerald, op. cit., (2001) for a discussion of ways in which CMS missionaries attempted to re-create 'home' in a colonial landscape.
} 
permanent residence in New Zealand. ${ }^{76}$ More specifically, Jane Williams acknowledged that 'although all intercourse with our much loved English females is cut off, we possess the same sources of comfort and happiness with them' ${ }^{77}$ While geographical separation may have been painful, the space that was carved out was familiar, self-supporting and non-restrictive and readers were invited to participate. For example, in her diary entry in June 1826, Marianne recorded that:

Mondays and Tuesdays are the only evenings in the week we spend by ourselves, and many a time do we exclaim on these comfortable nights as we call them. How I wish our mother could see us. Indeed when we first met, past times were so forcibly brought to my view. I frequently of an evening could have almost fancied I heard her voice curtailing our gossiping and chiding us off to bed. Jane and I have got through a world of business and I often smile at your wondering what we should set about. ${ }^{78}$

This sense of isolation was felt more deeply during periods of ill health, pregnancy and family stress. For example, after the death of Catherine's husband Edward Heathcote in 1835, Jane urged her sister-in-law 'released as you are from every tie to your present home'79 to 'dissolve your nearest and dearest ties and make up your mind to come over and help us'. ${ }^{80}$ Descriptions contained in this letter provide a sense of textual connection. The world of the mission station in Paihia and the church community in Southwell was itself a text to draw on and record the circumstances of their everyday lives and activities. Images such as the family at prayer each evening, teaching in schools, Sunday services and the writing of letters link women in a network of perceptions. Images invoked and the language of these letters and diaries are both anecdotal and personal; it is as if the writer is speaking to her reader and that both are included in the construction of the narrative and images. For example, in a letter written in 1826, Marianne included herself, her sister-in-law and her readers in the text through the use of personal pronouns:

Jane and I have got a world of business and I often smile at you wondering what we should set about ... we often amuse ourselves with castle building for this little pair and fancy Thomas and Mary Williams

\footnotetext{
76 Jane Williams, 3 March 1826, Letters \& Journals, Vol. 1, pp. 32-33, ATL.

77 Jane Williams, 3 March 1826, Letters \& Journals, Vol. 1, p. 33, ATL.

78 Marianne Williams, 15 June 1826, Letters \& Journals, Vol. 1, p. 24, ATL.

${ }^{79}$ Jane Williams to Catherine Heathcote, 31 October 1835, Williams Papers, Box 11, Folder 98, Item 707, AMI.

80 Jane Williams to Catherine Heathcote, 30 October 1835, Williams Papers, Box 11, Folder 98, Item 707, AMI.
} 
may perhaps come over again in the third generation. ${ }^{81}$

The way in which this letter has been written has invited a sense of participation in activities within a personal circle of close friends. It is as if the reader(s) and writer shared the same place and space. For example in a later letter, Marianne proposed that she invite you to go with me up the hill on which the Chapel stands' ${ }^{82}$ This sense of community and commonality of interest between writer and reader is evident in the drawing together of the network of 'sisters'. On the one hand while this textual connection between women correspondents existed to establish a network of evangelical women, on the other hand there was simultaneously a tactical connection in operation. Although included in the Paihia mission community and Marianne and Jane's educative activities, the language of co-option used in their correspondence drew implicit support for the evangelising project; the salvation of Nga Puhi women via the agency of schooling.

One of the ways in which the imperial project linked metropole and periphery was through the exchange of supplies such as frocks and gowns as well as 'pictures of saints and religious scenes for the schoolroom walls' ${ }^{83}$ sent by the women of the Southwell parish as a contribution to 'our sphere of usefulness' ${ }^{84}$ A plea for assistance with goods from 'our fellow women' provided an opportunity for English middle class women to directly participate in the rescue of Nga Puhi women. ${ }^{85}$ Henry Williams made one such plea in 1828:

I wish to excite a little sympathy in some of your charitable minds on behalf of your sisters in this land who are not less forlorn than those in India. They stand unprotected by any but exposed to all, and as the mothers of future generations we have felt much on their account. Amongst our small body we have raised a fund which we may control ourselves. By sending some dresses according to the pattern sent by Marianne and Jane you will greatly contribute to their relief. ${ }^{86}$

Both Marianne and Jane received gifts from their friends 'to intend whatever I send to be put, when arrived, to the most convenient use for either of my sisters' ${ }^{87}$ Items such as a

\footnotetext{
${ }^{81}$ Marianne Williams, 15 June 1826, Letters \& Journals, Vol. 2, p. 24, ATL.

${ }^{82}$ Marianne Williams, 26 December 1829, Henry Williams \& Marianne Williams, William Williams \& Jane Williams, Letters \& Papers, n.d., Series B, Vol. F, typescript, MS335, AMI.

83 Marianne Williams, 10 July 1826, Letters \& Journals, Vol. 1, p. 40, ATL.

${ }^{84}$ Jane Williams to Catherine Heathcote, 24 April 1837, Williams Papers, Box 11, Folder 99, Item 711, AMI.

${ }^{85}$ Lydia Marsh to Jane Williams, 21 February 1832, Williams Papers, Box 4, Folder 44, Item 276, AMI.

${ }^{86}$ Henry Williams, 22 September 1828, Letters, Vol. F, AMI.

${ }^{87}$ Lydia Marsh to Jane Williams, 21 February 1832, Williams Papers, Box 4, Folder 44, Item 276, AMI.
} 
kettle holder and teapot stand received by Jane in 1835 were gratefully received. As Jane recorded 'all these little things we attach a great deal of value as they serve to remind us of much loved friends, and are proofs of the continuance of their affection for us'. ${ }^{88}$ Partially to reciprocate in the giving of gifts and partially to provide evidence of their evangelical work, Marianne and Jane also sent items of clothing to their friends. These clothes were made by Nga Puhi women as part of their schooling and the women in Southwell 'gladly distributed' these specimens to encourage others to support missionary endeavours. ${ }^{89}$ As commented by Marianne in 1830:

I have saved some specimens of work to send you. I think the progress our girls have made will gratify you, and I hope the art of sewing may by the Lord's blessing be the least part of the good they obtain. ${ }^{90}$

Because neither Marianne nor Jane was familiar with the attributes of Maori womanhood they consequently agreed with assumptions that Maori women were 'degraded', 'savage' and 'heathen'. ${ }^{91}$ Such views therefore shaped the relationship between missionary women and Maori women and via their letter and journal writing, Marianne and Jane Williams acted as cultural agents and producers. This supports arguments forwarded by Mary Louise Pratt and Susan Morgan that subtle accounts such as these shaped and defined the colonial gaze. ${ }^{92}$ Sara Mills has offered the argument that within a defined geographical place and time, social space existed that opened up the possibility for women to interrogate and negotiate their own position. Frequently, this was an oppositional space that operated for (white) men and women and Indigenous people in different ways. ${ }^{93}$ In colonial texts such as missionary women's letters and diaries, friendships between and among women and ways in which Nga Puhi women are constructed map out relations between coloniser and colonised.

Yet not all (white) women in the Paihia mission station were included in the network of sisterhood or evangelical work, namely teaching in one of the mission schools. ${ }^{94}$ While the language of sisterhood was used to structure women's evangelical

\footnotetext{
88 Jane Williams to Catherine Heathcote, 2 December 1835, Williams Papers, Box 11, Folder 98, Item 708, AMI.

${ }^{89}$ Lydia Marsh to Jane Williams, 21 February 1821, Williams Papers, Box 4, Folder 44, Item 276, AMI.

90 Marianne Williams, 7 February 1830, Letters, Vol. F, AMI.

${ }^{91}$ Henry Williams to Dandeson Coates, 13 May 1826, Letters to Church Missionary Society from Henry Williams, n.d., Vol. 1, p. 145, typescript, qMS2230, ATL.

92 Pratt, op. cit., (1992); Morgan, op. cit., 1996.

${ }^{93}$ S. Mills, 'Gender and Colonial Space', Gender, Place \& Culture: A Journal of Feminist Geography. 3/2 (1996), $125-147$.

${ }^{94}$ Fitzgerald, op. cit., (1995) argues that in the 1823-1828 period there were four separate schools established in Paihia: for Maori girls (1823); for Maori boys (1824); for daughters of resident missionary families (1825); and for sons of missionaries (1828).
} 
identities, this rhetoric was also used to rework identities based on class and position and highlight social differences among women that created what Alison Twells calls a cultural hierarchy. ${ }^{95}$ It is possible therefore that the version of sisterhood exercised by Marianne and Jane and their Southwell sisters was based on unequal relationships that resulted in those deemed to be 'sisters' speaking and acting on behalf of those who were excluded from this network. Martha Blomfield Clarke, for example, although described by Jane Williams as 'a very nice young woman . . is not a sister' ${ }^{96}$ One reason for this statement may have been that Martha's husband, George Clarke, had been a carpenter and gunsmith prior to his recruitment as a missionary and Henry Williams and William Williams as a retired Naval officer and medical practitioner respectively, were of a different social class. ${ }^{97}$ Although not a great deal is known of Jane Williams early life, Marianne's father, Wright Coldham, had been Sheriff of Nottingham and involved with the lace industry as had Henry's family. ${ }^{98}$ Jane's connection with the family was brokered when she taught in Mary Williams' school in Southwell, Nottinghamshire where she met and eventually married Mary's son, William. ${ }^{99}$ Those women with whom Marianne and Jane identified strongly were their sisters: women with similar backgrounds, education and attributes. ${ }^{100}$ As Jane Haggis and Susanne Schech have argued, women missionaries constructed their 'missions of sisterhood' around intersections of race privilege and Christian prescriptions of femininity that drew on contemporary nineteenth century ideology. 101

When Jane and William Williams moved inland to the mission station at Waimate in 1835 , the two women continued to exchange letters they wrote and received. In one of her many letters to Catherine Williams Heathcote, Jane commented that:

Marianne and I have not now the pleasure of receiving and sending our letters together but we exchange them as soon as we can and so double our gratification; still we should much enjoy an hour's chat over our various intelligence. I much fear that you will not hear from her by this ship, she is in such a complete bustle, with the arrival of new friends

\footnotetext{
${ }^{95}$ Twells, op. cit., (1998).

96 Jane Williams to Catherine Heathcote, 29 May 1835, Williams Papers, Box 3, Folder 98, Item 706, AMI. The underlining appears in the original letter.

${ }^{97}$ R. Fisher, 'Henry Williams 1792-1867', DNZB Vol. 1, 593-594: F. Porter, 'William Williams 1800-1878', DNZB Vol. 1, 597-598.

${ }^{98}$ S. Williams, op. cit. (1990).

${ }^{99}$ F. Porter, 'Jane Williams 1801?-1896', DNZB Vol. 1, 594-595.

${ }^{100}$ Lydia Marsh to Jane Williams, 5 September 1833, Williams Papers, Box 1, Folder 44, Item 279, AMI.

101 J. Haggis \& S. Schech, 'Meaning Well and Global Good Manners: Reflections on White Western Feminist Cross-cultural Praxis', Australian Feminist Studies, 15/3 (2000), 387-399.
} 
with supplies. ${ }^{102}$

\section{Conclusion}

As a record of women's missionary women and encounters between missionary women and Maori women, letters and diaries written by Marianne and Jane Williams are critical artefacts of colonial authority. Drawing on accounts of their work and educative activities, Marianne and Jane articulate ways in which they experienced their relationship with other missionary women and 'other' Indigenous women. The intersection of race and religion was one of the primary axes around which relations among and between women were situated. On one level this relationship was forged among equals; evangelical women in Paihia and Southwell. On another level this was a relationship based on an unequal relationship between Pakeha women and Nga Puhi women; a relationship in which Marianne and Jane Williams exerted evangelical and maternal authority over their Maori pupils. In the colonial context therefore, the interconnection of race, religion, sisterhood and motherhood provided the space in which cartographies of friendship were played out.

Mapping is a distinctive form of spatial representation because it can be interpreted as visual and/or textual as this article has shown. To read correspondence between/among evangelical women in the early nineteenth century as texts highlights their central social construction and the potential for multiple interpretations by writer and reader(s). The spatial imagery contained in photographs as well as letters and diaries can expose ways in which the production of viewing/reading images can re-present the colonial 'other' and present what Jane Haggis suggests is an exclusionary and ethnocentric discourse that potentially makes white women visible at the expense of colonised women. 103

This article has mapped Marianne and Jane's everyday relationships and identities within specific spaces and geographical location. Although reasons for detailing their lives and educative activities are deeply ambiguous, it is important to consider why and when these stories were told and retold as well as the author and her audience.

\footnotetext{
102 Jane Williams to Catherine Heathcote, 2 December 1835, Williams Papers, Box 11, Folder 98, Item 708, AMI.

103 J. Haggis, 'Gendering Colonialism or Colonising Gender? Recent Women's Studies Approaches to White Women and the History of British Colonialism', Women's Studies International Forum, 1/2 (1990), 105-115.
} 